\title{
Göllerde Su Bütçesi Hesaplaması: Uluabat Gölü Örneği
}

\author{
Saadet Hacısalihoğlu'* Feza Karaer² \\ 'Bursa Teknik Üniversitesi Doğa Bilimleri ve Mühendislik Fakültesi Çevre Mühendisliği, Bursa \\ ²Uludağ Üniversitesi Mühendislik Fakültesi Çevre Mühendisliği Bölümü, Bursa
}

\author{
*Sorumlu yazar e-mail (Corresponding author e-mail): saadet.hacisalihoglu@btu.edu.tr \\ Geliș tarihi (Received): 31.05.2018 \\ Kabul tarihi (Accepted): 29.08.2018 \\ DOI: $10.21657 /$ topraksu. 460717
}

\section{Öz}

Bu çalıșmada ülkemizin sahip olduğu önemli sığ göllerden biri olan Uluabat Gölü'nün su bütçesinin Ağustos 2013-Temmuz 2014 dönemlerini kapsayacak șekilde hesaplanması amaçlanmıștır. Gölün su bütçesinin hesaplanmasında en büyük eksiklik düzenli ölçülmüș verilerin bulunmayıșıdır. Bir gölün su bütçesi, ölçülmüș veya tespit edilmiș gölün su kayıp ve kazançları ile aynı zaman periyodu içinde göl hacmindeki değișimin kıyaslanarak hesaplanmasıdır. Uluabat Gölü'nün beslenimi özellikle yağıș, yüzey suyu, drenaj suları ve yeraltı suyu akımı ile sağlanmaktadır. Gölün boșalım elemanları ise buharlașma ve sulama için alınan sulardır. Çalıșma sonucunda, 2013-2014 su yılında gölün beslenimi ile boșalımı arasındaki mutlak fark $53.2 \mathrm{hm}^{3}$ olarak hesaplanmıștır. Bağıl hata ise $4.4 \mathrm{hm}^{3}$ bulunmuștur. Bu durum, genel anlamda gölde kaçak su çekimlerinin olduğunu veya gölün yeraltı suyunu beslediğini göstermektedir.

Anahtar Kelimeler: uluabat gölü, su bütçesi, su seviyesi, yağıș miktarı, yeraltı su seviyesi

\section{Calculation of Water Budget in Lakes, Example Lake Uluabat}

\begin{abstract}
In this study, it is aimed to calculate the water budget of Lake Uluabat to cover from August 2013 to July 2014, one of the important shallow lakes that Turkey has. The lack of regularly measured data is the biggest problem in calculation of water budget of the lake. A lake water budget is computed by measuring or estimating all of the lake's water gains and losses and measuring the corresponding changes in the lake volume over the same time period. Recharge of the lake is supplied from especially precipitation, drainage, surface and subsurface water inflow. The discharge components of the lake are evaporation and water intake for irrigation. The absolute difference between recharge and discharge of the lake was calculated as $53.2 \mathrm{hm}^{3}$ for 2013-2014 water year period. The relative error was found $4.4 \mathrm{hm}^{3}$. In general, this situation shows that there are illegal water catches in the lake or that the lake feeds underground water.
\end{abstract}

Key words: lake uluabat, water budget, water level, rainfall, underground water level 


\section{Giriș}

Günümüzde artan dünya nüfusu ve giderek azalan temiz su kaynakları nedeniyle mevcut su kaynaklarının etkin ve sürdürülebilir yönetimi büyük önem tașımaktadır (Șanlı ve Doğan 2015). Su kaynaklarının istenilen zaman, mekan, kalite ve miktarda teminine yönelik olarak yașanan sıkıntılar, konuya ilișkin dünya çapında sürdürülebilir yönetim ilke ve kararlarının alınmasını ve uygulanmasını zorunlu hale getirmiștir (Davraz ve Balın 2015). Su kaynaklarında sürdürülebilir kullanım için göllerin su bütçelerinin belirlenmesi gerekir. Göl yönetiminde bașlıca problemlerden biri su bütçesi elemanlarının tespitidir. Su bütçesinin hesaplanmasında karșılașılan en büyük problem düzenli ölçümlerin bulunmayıșıdır. Bir gölün su bütçesi, gölde ölçülmüș veya tespit edilmiș su kayıp ve kazançları ile aynı zaman periyodu içinde göl hacmindeki değișimin kıyaslanarak hesaplanmasıdır (Davraz ve diğ. 2014, Sarmașık 2012). Bașka bir ifade ile su bütçesi, bir ekosistemde belirli bir süre içinde sisteme giren su ile çıkan ve depolanan suyun denge durumunda bulunması șeklinde tanımlanabilir (Șener ve Soyaslan 2006, Șorman 2008). Su bütçesini olușturan parametreler; yağıș, buharlașma, yeraltı suyu beslemeleri, dereler ve çekilen su miktarları olarak kabul edilen girdi ve çıtılardır (Davraz ve Balın 2015). Göllerde su seviyesi, sulamada kullanılan sular, izinsiz su çekimleri ve iklim koșulları nedeniyle sürekli değișmelere maruz kalmaktadır. Bu değișimin ne kadarının iklimden kaynaklandığı ne kadarının su kullanımından kaynaklandığının belirsizliğini koruması sürekli bir tartıșma konusu olmaktadır. Bu nedenlerden dolayı su bütçesi gerek eksik veriler ve gerekse hassas yapıllamayan ölçümler nedeniyle belirli bir hata payı ile hesaplanır (Mercan 2006).

Uluabat Gölü, Türkiye'nin en önemli sığ göllerinden biri olup farklı amaçlar için kullanımından dolayı bölgenin en önemli su kaynaklarındandır. Bu çalıșmada, gölün mevcut bütçe bileșenleri kullanılarak Ağustos 2013-Temmuz 2014 dönemlerini kapsayan süreçte aylık ve yıllık su bütçesi değișiminin hesaplanması amaçlanmıștır.

\section{MATERYAL VE YÖNTEM}

\section{Uluabat Gölü Genel Özellikleri}

Uluabat Gölü, Marmara denizinin 15 km güneyinde ve Bursa ilinin 30 km batısında, 40 10' kuzey enlemi $28^{\circ} 35^{\prime}$ batı boylamı arasında yer almaktadır. Doğu-batı yönündeki uzunluğu yaklașık olarak 22 km, kuzey-güney yönündeki genișliği ise 10,5 km kadardır. Alanları 0,25 ha (Heybeli Adası) ile 190 ha (Halilbey Adası) arasında değișen büyüklüklerde sekiz adayı içeren, büyük ve sığ bir tatlı su gölüdür. Gölün denizden yüksekliği yaklașık olarak 9 m'dir (Hacısalihoğlu 2016).

Göl ortalama 2,5 m derinliğe sahiptir. Ancak bu derinlik yıldan yıla ve yaz ile kıș mevsimleri arasında önemli miktarlarda değișmektedir. Öyle ki, yaz aylarında bu derinlik 0,5-1 m kadar gerilerken, kıș aylarında maksimum 4,5 m derinlik ölçülmüștür. Illeri (2010) çalıșmasında ortalama derinliğin kurak ve yağıșlı aylarda 1,5 ile 3,45 m arasında değiștiğini tespit etmiștir. Su seviyesi genellikle kıș mevsiminde yüksek ve yazları (su girdisinin az olușu, buharlașma ve gölden yapılan tarım amaçlı su çekimlerinin etkisiyle) düșüktür. Daha önce göl ile ilgili olarak hazırlanan raporlarda ve gölü tanıtan verilerde normal su seviyesinde göl yüzey alanı 160 km² olarak belirlenmiștir. Ancak 1998 yılında yapılan çalıșmada ise Uluabat Gölü alanının 116 km²'ye gerilediği belirlenmiștir (Aksoy ve Özsoy 2002).

Mustafakemalpașa (MKP) Çayı, gölü besleyen en önemli akarsudur. Çayın debisi ve su kalitesi iklimsel koșullara bağı olarak değișiklik göstermektedir. 1939 ile 1969 yılları arasında 30 yıllık ortalamaya göre tașıdığı su hacmi 500×106 $\mathrm{m}^{3}$ ile $4000 \times 10^{6} \mathrm{~m}^{3}$ arasında değișim göstermiștir (Sarmașık 2012). Ayrıca gölün doğusunda Akçalar Köyü'nde bulunan Akçalar Deresi de debisi oldukça düșük olmasına rağmen gölü besleyen yüzeysel bir su kaynağıdır. Göl havzası üzerinde yapımı 2011 yılında tamamlanan Çınarcık



Șekil 1. Uluabat Gölü Uydu Görüntüsü

Figure 1. Satellite View of Lake Uluabat 
Barajı Kuvvet Tüneli ile de göle önemli miktarda havzadan toplanan sular iletilmektedir.

Gölün drenajı batıda, Uluabat Köyüyöresindeki, nihayetinde Marmara Denizi'ne dökülen Kocasu Çayı vasıtasıyladır. Uluabat Gölü tipik bir sığ göldür. Sığ göllerin tipik özelliği olarak rüzgarın etkisiyle tam karıșıma uğrar, ıșık erișilebilirliğinin belirlendiği litoral bölgesi geniștir (Sarmașik 2012). Yüzeysel sularında gösterildiği Uluabat Gölü'ne ait uydu görüntüsü Șekil 1'de sunulmuștur.

\section{Su Bütçesinin Hazırlanması}

Suve su kaynaklarıileilgilisorunlarınçözümünde su bütçesinin bilinmesi büyük önem tașımaktadır. Farklı amaçlarla su bütçesini ortaya koymak için, ele alınan havzanın ya da alanın büyüklüğüne ve elde edilecek verilere göre temelde aynı olmasına karșın içerdiği öğeler bakımından farklı birçok su bütçesi denklemi mevcuttur (Baumgartner ve Reichel 1975, Hyfield ve diğ. 2008, Lawrie ve Stretch 2011). Genel ifade ile yaygın kullanılan denklemler așağıda verilmiștir.

$$
\frac{\mathrm{dV}}{\mathrm{dt}}=\mathrm{O}_{\text {giren }}-\mathrm{O}_{\text {cikan }}
$$

Suvesu kaynaklarıileilgilisorunlarınçözümünde su bütçesinin bilinmesi büyük önem tașımaktadır. Farklı amaçlarla su bütçesini ortaya koymak için, ele alınan havzanın ya da alanın büyüklüğüne ve elde edilecek verilere göre temelde aynı olmasına karșın içerdiği öğeler bakımından farklı birçok su bütçesi denklemi mevcuttur (Baumgartner ve Reichel 1975, Hyfield ve diğ. 2008, Lawrie ve Stretch 2011). Genel ifade ile yaygın kullanılan denklemler așağıda verilmiștir.

$\mathrm{dV} / \mathrm{dt}=\mathrm{O}_{\text {dere }}+\mathrm{O}_{\text {yā̄̆s }} \mathrm{O}_{\text {dere }} \mathrm{O}_{\text {sulama }}$ Buharlașma Eșitlik (2)

Yukarıdaki denklemlerde görüldüğü üzere göllerde su bütçesi genel bileșenleri Șekil 2'de de görsel olarak sunulmuștur. Uluabat Gölü'nde su bütçesinin olușturulması așamasında öncelikli olarak göle giren ve gölden çıkıș yapan sular için çalıșma dönemine ait Devlet Su İșleriı. Bölge Müdürlüğü (DSi)'den edinilen debi değerlerinden faydalanılmıștır. Uluabat Gölü çanağını besleyen ana akım MKP Çayı üzerinde ișletilen akım gözlem istasyonuna ait günlük veriler bulunmasına karșın, gölün çıkıș ayağında bulunan Kocasu Çayı'ndaki akım gözlem istasyonuna ait veriler bulunmamaktadır. Bu nedenle, göle ait su bütçesinin olușturulabilmesi amacı ile Ağustos 2013-Temmuz 2014 dönemini kapsayan her ay bu su kaynağı üzerinde DSi personeli yardımı ile debi ölçümü yapıımıștır. Benzer șekilde aynı gün içerisinde Akçalar deresinde de el tipi muline yardımı ile debi ölçümü gerçekleștirilmiștir. Ayrıca gölde bulunan sabit su kotu, hesaplamalarda kullanılmak üzere kaydedilmiștir. Çalıșmada yapılan ölçümler ile ilgili fotoğraflar Șekil 3'de sunulmuștur. Göle giriș yapan bir diğer su kaynağı Çınarcık kuvvet tüneli olup, bu tünelin ișletimini yapan firma ile görüșmeler sonucu barajdan göle salınan aylık ortalama su miktarları temin edilmiștir. Su bütçesinin olușturulması așamasında, temel yüzeysel su kaynaklarının debilerinin belirlenmesi sonrası, göle giren ve çıkan diğer noktasal su kaynakları DSi'den öğrenilmiș, arazide keșifler yapılmıș ve bu noktalardaki debi değerleri de temin edilmiștir. Buna göre gölden sulama amaçlı su çeken (Yenikaraağaç sulama) pompa istasyonlarına ait aylık çalıșma saatleri, ölçülen pompa kapasiteleri (m³/saat) DSi'den temin edilmiștir. Pompa istasyonlarının sulamaya açilıș ve kapanıș tarihleri de hesaba katılarak pompa istasyonlarına ait su çekimleri günlük olarak hesaplandıktan sonra aylık değerlere geçiș yapılmıștır. Göl etrafında sulamadan dönen drenaj sularının toplanıp göle iletilmesini sağlayan iki farklı pompa istasyonu daha bulunmaktadır. Bunlar, Atabay ve Karaoğlan pompa istasyonları olarak isimlendirilmiștir. Yine bu pompa istasyonlarına ait aylık çalıșma saatleri, ölçülen pompa kapasiteleri ( $\mathrm{m}^{3}$ /saat), pompaların açlıș ve kapanıș tarihleri de hesaba katılarak göle deșarj ettikleri su miktarları günlük olarak hesaplandıktan sonra aylık değerlere geçiș yapılmıștır. Su bütçesini olușturan diğer su bütçe elemanları meteorolojik olaylar ile ilgili

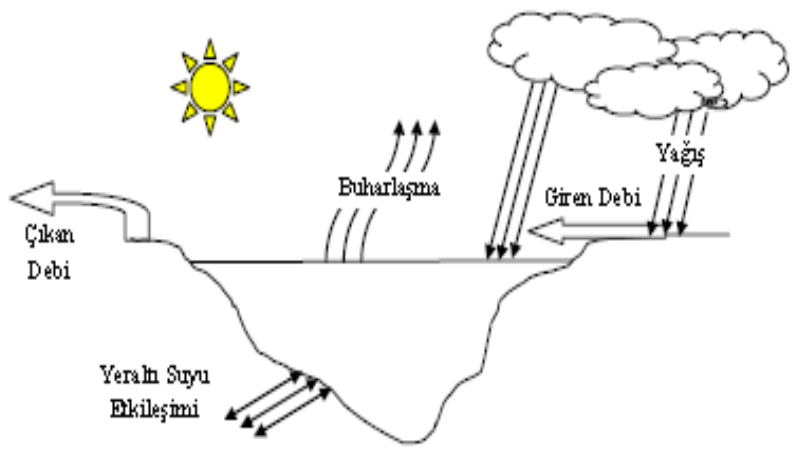

Șekil 2. Göllerde Genel Su Bütçesi

Figure 2. General Water Budget in Lakes 


\section{toprägs u.}

(a)

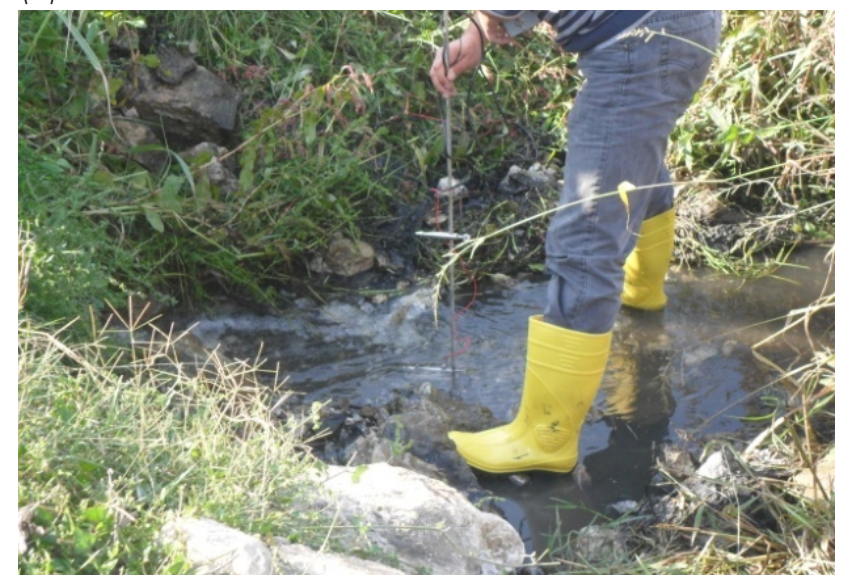

(c)



S.Hacısalihoğlu, F. Karaer

(b)

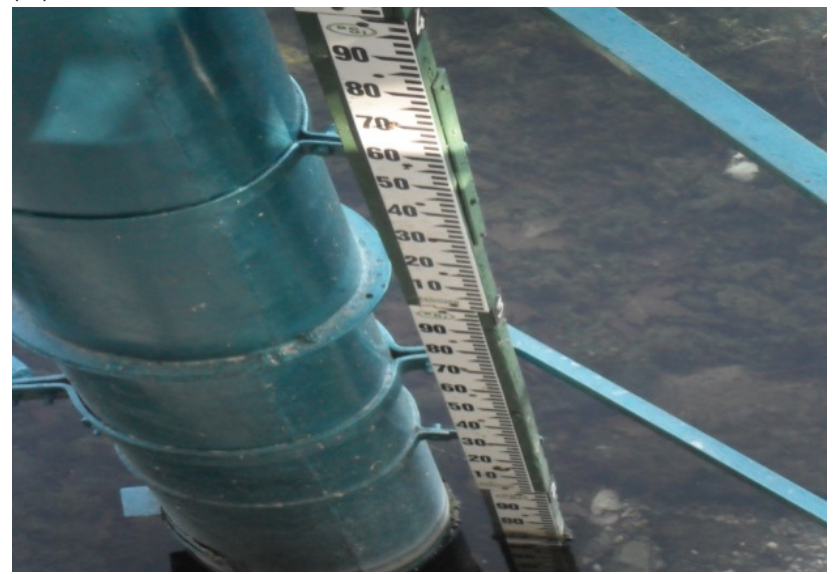

(d)

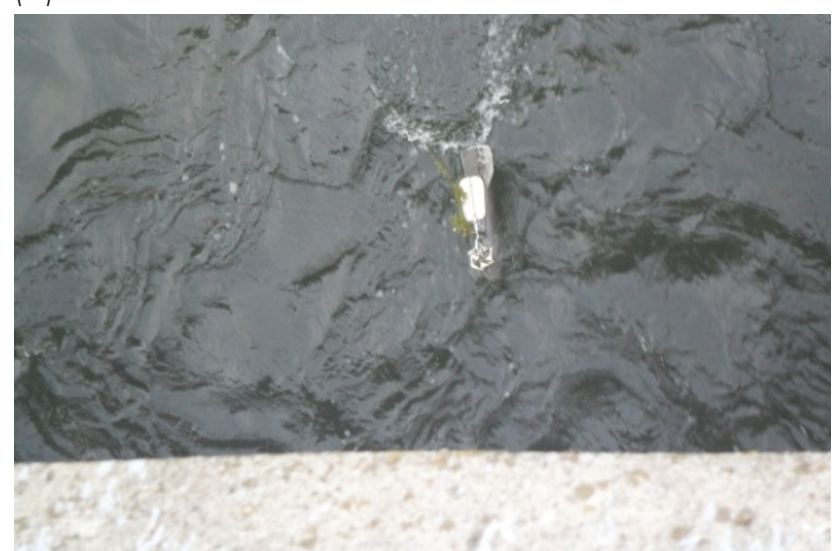

Șekil 3. (a) Akçalar Deresi Debi Ölçümü, (b) Göl Su Kotu, (c) Kocasu Çayı'nda Debi Ölçümü (Uluabat Köprüsü Üzerinden), (d) Köprüden Sarkıtılan Muline

Figure 3. (a) Flow Measurement of Akçalar Creek, (b) Lake Water Level, (c) Flow Measurement in Kocasu Stream (From Uluabat Bridge), (d) Muline hanging from the bridge

olan buharlașma ve yağıș faktörleridir. Bu bütçe elemanlarının hesaplanması așamasında göle en yakın meteoroloji istasyonu olan Karacabey Meteoroloji İstasyonundan buharlașma miktarları (mm) ve göl aynasına düșen yağıș yüksekliği $(\mathrm{mm})$ verileri temin edilmiștir. Toplam buharlașma hacmi $\left(\mathrm{m}^{3}\right)$ hesaplanırken, meteoroloji istasyonu tarafından tava (kap) katsayısı olarak ifade edilen ve 0,7 olarak belirlenen sabit katsayı değeri ile buharlașma miktarı $(\mathrm{mm})$ ve göl yüzey alanı $\left(\mathrm{m}^{2}\right)$ çarpıllarak belirlenmiștir. Yine benzer șekilde toplam yağıș hacmi $\left(\mathrm{m}^{3}\right)$, yağıș miktarı $(\mathrm{mm})$ ve göl yüzey alanı $\left(\mathrm{m}^{2}\right)$ çarpılarak hesaplanmıștır. Gölün yüzey alanı hesaplanırken, 2010 yılında yapılan güncel göl batimetresi kullanılmıștır. Burada hacim-alan ilișkisine dayalı, su kotu ve bu değere karșllık gelen göl yüzey alanı batimetre yardımıyla belirlenmiștir. DSi tarafından göle ait su kotu değerleri günlük olarak kaydedilmektedir. Bu değerlerin aylık ortalaması alınarak, aylık ortalama su kotuna karșılık gelen göl hacmi ve göl yüzey alanı belirlenmiștir. Bu değerler bulgular ve tartıșma kısmında sunulmuștur. Su bütçesi hesaplamalarında kullanılan bir diğer bütçe elemanı yeraltı suyu miktarıdır. Uluabat Gölü'nün yeraltı suyu ile etkileșim içerisinde olduğu bilinmektedir. Uluabat Gölü'ne ait su bütçesi elemanları eksik veriler ve hassas yapılamayan ölçümler nedeniyle belirli bir hata payı ile hesaplanabilmiștir. Ölçüm eksikliği sebebiyle yeraltı suyuna ait veri bulunmadığından bu bütçe elemanının hata payı içerisinde yer aldığı varsayıımıștır. Buna göre su bütçesi genel denklemi;

Hacim Değișimi = Toplam Gelen Su-Toplam Çıkan Su \pm Hata

Eșitlik (3)

șeklinde ifade edilebilir (Mercan 2006, Sarmașık 2012). Hata değerlerinin negatif olması gölün beslendiğini, pozitif olması ise gölden su çekiminin olduğunu ifade etmektedir (Mercan 2006).

\section{BULGULAR VE TARTIȘMA}

Su kaynaklarının sürdürülebilir yönetimi konusunda dünyada yapılan çalıșmalar, havza 
bazlı yönetim ve sürdürülebilirlik konuları üzerinde odaklanmıștır (Davraz ve diğ. 2016, Șanlı ve Doğan 2015, Lallahem ve Mania 2003). Havza ölçeğinde su kaynaklarında gerek miktar gerekse nitelik olarak meydana gelen değișikliklerin gözlenmesi, herhangi bir olumsuz durumda gerekli önlemlerin alınması açısından da avantaj sağlamaktadır. Havzalarda su potansiyeli hidrolojik çalıșmalar ile belirlenmektedir. Bu değerlendirmenin yapılabilmesi için hidrolojik bütçe elemanlarının (yağıș, akıș, buharlașma ve sızma) kütlenin korunumu prensibine dayanan su dengesi denklemi ile hesaplanması gerekmektedir (Cook ve diğ. 2008). Bu bağlamda Uluabat Gölü'nde su dengesinin kurulması amacı ile su bütçesi elemanları belirlenmiș ve belirli hata payı ile su bütçesi olușturulmuștur.

Uluabat Gölü su bütçesi elemanları ve

Çizelge 1. Uluabat Gölü Su Bütçesi Elemanları ve Aylık Değișimleri

Table 1. Water Budget Elements of Lake Uluabat and Monthly Changes

\begin{tabular}{|c|c|c|c|c|c|c|c|c|c|c|c|c|}
\hline \multicolumn{13}{|c|}{ GÖLDEN ÇIKAN SU MIKTARI } \\
\hline & $\begin{array}{l}\text { Su Kotu } \\
\text { (m) }\end{array}$ & $\begin{array}{l}\text { Hacir } \\
\left\langle\mathrm{hm}^{3}\right.\end{array}$ & $\begin{array}{r}\text { Kocas } \\
\text { Çayı } \\
\left(\mathrm{hm}^{3}\right. \\
\end{array}$ & \multicolumn{2}{|c|}{$\begin{array}{c}\text { Sulama } \\
\left(\mathrm{hm}^{3}\right)\end{array}$} & \multicolumn{2}{|c|}{$\begin{array}{l}\text { Buharlașma } \\
\qquad(\mathrm{mm})\end{array}$} & $\begin{array}{c}\text { Kap } \\
\text { Katsayısı }\end{array}$ & $\begin{array}{c}\text { Göl Alanı } \\
\left(\mathrm{km}^{2}\right)\end{array}$ & \multicolumn{2}{|c|}{$\begin{array}{c}\text { Toplam } \\
\text { Buharlașma } \\
\left(\mathrm{hm}^{3}\right)\end{array}$} & $\begin{array}{c}\text { Toplam } \\
\text { Çıan Su } \\
\left(\mathrm{hm}^{3}\right) \\
\end{array}$ \\
\hline Ağu.13 & 2,50 & 132,0 & 33,78 & \multicolumn{2}{|c|}{3,64} & \multicolumn{2}{|l|}{162,1} & 0,70 & 129,50 & \multicolumn{2}{|c|}{14,69} & 52,11 \\
\hline Eyl. 13 & 2,47 & 127,0 & 33,53 & \multicolumn{2}{|c|}{1,25} & \multicolumn{2}{|l|}{106,0} & 0,70 & 127,80 & \multicolumn{2}{|l|}{9,52} & 44,31 \\
\hline Eki.13 & 3,45 & 267,0 & 37,75 & \multicolumn{2}{|c|}{0,00} & \multicolumn{2}{|l|}{36,6} & 0,70 & 127,80 & \multicolumn{2}{|l|}{3,27} & 41,03 \\
\hline Kas. 13 & 2,55 & 138,0 & 36,08 & \multicolumn{2}{|c|}{0,00} & \multicolumn{2}{|l|}{33,7} & 0,70 & 129,50 & \multicolumn{2}{|l|}{3,05} & 39,13 \\
\hline Ara. 13 & 3,47 & 270,0 & 66,98 & \multicolumn{2}{|c|}{0,00} & \multicolumn{2}{|l|}{33,9} & 0,70 & 145,60 & \multicolumn{2}{|l|}{3,45} & 70,44 \\
\hline Oca. 14 & 2,62 & 148,0 & 49,17 & \multicolumn{2}{|c|}{0,00} & \multicolumn{2}{|l|}{38,3} & 0,70 & 131,20 & 3,51 & & 52,69 \\
\hline Șub. 14 & 2,62 & 148,0 & 45,36 & 0,00 & & 39,0 & & 0,70 & 131,20 & 3,58 & & 48,94 \\
\hline Mar. 14 & 2,72 & 161,0 & 53,96 & 0,00 & & 63,5 & & 0,70 & 132,90 & 5,91 & & 59,87 \\
\hline Nis. 14 & 2,72 & 161,0 & 49,92 & 0,00 & & 85,0 & & 0,70 & 132,90 & 7,91 & & 57,83 \\
\hline May. 14 & 2,82 & 175,0 & 98,69 & 0,47 & & 114,0 & & 0,70 & 134,60 & 10,7 & & 109,9 \\
\hline Haz. 14 & 2,72 & 161,0 & 73,63 & 1,20 & & 134,4 & & 0,70 & 132,90 & 12,50 & & 87,34 \\
\hline Tem. 14 & 2,59 & 144,0 & 44,83 & 3,84 & & 161,8 & & 0,70 & 131,20 & 14,86 & & 63,54 \\
\hline & & & & & ق & ELET & I SU MiK & KTARI & & & & \\
\hline & $\begin{array}{l}\text { Su } \\
\text { Kotu } \\
(\mathrm{m})\end{array}$ & $\begin{array}{l}\text { Hacim } \\
\left(\mathrm{hm}^{3}\right)\end{array}$ & $\begin{array}{l}\text { C.ınarcık } \\
\text { Barajı } \\
\left(\mathrm{hm}^{3}\right)\end{array}$ & $\begin{array}{l}\text { Atabay } \\
\mathrm{Pi} \\
\left(\mathrm{hm}^{3}\right)\end{array}$ & & $\begin{array}{l}\text { aoğlan } \\
\mathrm{Pi} \\
\mathrm{mm}^{3} \mid\end{array}$ & $\begin{array}{c}\text { Akçalar } \\
\left(\mathrm{hm}^{3}\right)\end{array}$ & ir $\begin{array}{c}\text { MKP } \\
\text { Çayı } \\
\left(\mathrm{hm}^{3}\right)\end{array}$ & $\begin{array}{l}\text { Yağıș } \\
\text { (mm) }\end{array}$ & $\begin{array}{l}\text { Göl } \\
\text { Alanı } \\
\left(\mathrm{km}^{2}\right)\end{array}$ & $\begin{array}{l}\text { Toplam } \\
\text { Yağıș } \\
\left(\mathrm{hm}^{3}\right)\end{array}$ & $\begin{array}{c}\text { Toplam } \\
\text { Gelen } \\
\text { Su }\left(\mathrm{hm}^{3}\right)\end{array}$ \\
\hline Ağu.13 & 2,50 & 132,0 & 13,28 & 2,61 & 0,46 & & 0,026 & 26,32 & 1,40 & 129,50 & 0,181 & 42,90 \\
\hline Eyl.13 & 2,47 & 127,0 & 12,31 & 1,75 & 0,47 & & 0,038 & 25,73 & 16,6 & 127,80 & 2,121 & 42,43 \\
\hline Eki.13 & 3,45 & 267,0 & 26,38 & 0,67 & 0,45 & & 0,010 & 29,73 & 763,4 & 127,80 & 97,56 & 154,81 \\
\hline Kas. 13 & 2,55 & 138,0 & 22,75 & 0,41 & 0,36 & & 0,012 & 17,98 & 60,8 & 129,50 & 7,873 & 49,41 \\
\hline Ara. 13 & 3,47 & 270,0 & 24,92 & 1,06 & 0,44 & & 0,016 & 15,85 & 38,6 & 145,60 & 5,620 & 47,93 \\
\hline Oca. 14 & 2,62 & 148,0 & 22,63 & 0,93 & 0,45 & & 0,053 & 18,75 & 30,8 & 131,20 & 4,040 & 46,86 \\
\hline Șub.14 & 2,62 & 148,0 & 15,26 & 0,54 & 0,36 & & 0,038 & 17,32 & 20,4 & 131,20 & 2,676 & 36,21 \\
\hline Mar. 14 & 2,72 & 161,0 & 21,32 & 0,55 & 0,41 & & 0,042 & 30,80 & 42,0 & 132,90 & 5,581 & 58,71 \\
\hline Nis. 14 & 2,72 & 161,0 & 20,29 & 0,48 & 0,38 & & 0,220 & 17,08 & 112,0 & 132,90 & 14,88 & 53,35 \\
\hline May. 14 & 2,82 & 175,0 & 41,83 & 1,09 & 0,61 & & 0,356 & 49,01 & 96,8 & 134,60 & 13,03 & 105,93 \\
\hline Haz. 14 & 2,72 & 161,0 & 35,35 & 1,55 & 0,49 & & 0,285 & 32,92 & 94,4 & 132,90 & 12,54 & 83,14 \\
\hline Tem. 14 & 2,59 & 144,0 & 22,31 & 1,71 & 0,15 & & 0,013 & 33,74 & 4,6 & 131,20 & 0,603 & 58,54 \\
\hline
\end{tabular}


bunların izleme süreci içerisinde aylık değișimleri tablolar halinde Çizelge 1'de verilmiștir. Çizelge 1 incelendiğinde, gölden çıkan su miktarını belirleyen bütçe elemanları, Kocasu Çayı, tarımsal sulama amaçlı çekilen su ve buharlașma faktörleridir. Her bir faktörün aylık değișim miktarları ve aylık toplam gölden çıkan su miktarları görülmektedir. Benzer șekilde göle gelen su miktarlarını belirleyen bütçe elemanları, Çınarcık Barajı Kuvvet Tüneli, MKP Çayı, Akçalar Deresi, Atabay ve Karaoğlan Pompa İstasyonları (Pi), göle düșen toplam yağıș miktarıdır. Her bir faktörün aylık değișim miktarları ve aylık toplam göle gelen su miktarları Çizelge 1'de görülmektedir.

Gölün su bütçesi, o göldeki su değișimini ve bu değișime etki eden parametreleri göstermesi açısından oldukça önemlidir (Ghale ve diğ. 2018). Her ne kadar bir gölün su bütçesi teorik olarak; girenlerden çıknnların farkı alınarak hacimsel değișime eșitlenmesinden ibaret olsa da, veri eksikliğinden ve ölçüm hatalarından kaynaklanan çeșitli belirsizlikler ortaya çıkabilmektedir. Eksik ölçümlerden dolayı su bütçesi denkleminde bilinmeyen sayısı artmaktadır. Bu durumda hesaplar ancak belirli bir hata payı ile yapılabilmektedir (Mercan 2006). Çalıșmada

Çizelge 2. Ağustos 2013-Temmuz 2014 Çalıșma Döneminde Ulluabat Gölü Genel Su Bütçesi

Table 2 General Water Budget of Lake Uluabat in August 2013-July 2014 Working Period

\begin{tabular}{lccccc}
\hline Dönem & $\begin{array}{c}\text { Su } \\
\text { Kotu } \\
(\mathrm{m})\end{array}$ & $\begin{array}{c}\text { Hacim } \\
\left(\mathrm{m}^{3}\right)\end{array}$ & $\begin{array}{c}\text { Toplam } \\
\text { Cıkan } \\
\text { Su } \\
\left(\mathrm{m}^{3}\right)\end{array}$ & $\begin{array}{c}\text { Toplam } \\
\text { Gelen } \\
\text { Su }\left(\mathrm{m}^{3}\right)\end{array}$ & $\begin{array}{c}\text { Gelen } \\
\text { Clkan }\end{array}$ \\
\hline Ağu.13 & 2,50 & 132,0 & 52,11 & 42,90 & $-9,21$ \\
\hline Eyl.13 & 2,47 & 127,0 & 44,31 & 42,43 & $-1,88$ \\
\hline Eki.13 & 3,45 & 267,0 & 41,03 & 154,81 & 113,78 \\
\hline Kas.13 & 2,55 & 138,0 & 39,13 & 49,41 & 10,28 \\
\hline Ara.13 & 3,47 & 270,0 & 70,44 & 47,93 & $-22,51$ \\
\hline Oca.14 & 2,62 & 148,0 & 52,69 & 46,86 & $-5,83$ \\
\hline Șb.14 & 2,62 & 148,0 & 48,94 & 36,21 & $-12,73$ \\
\hline Mar.14 & 2,72 & 161,0 & 59,87 & 58,71 & $-1,16$ \\
\hline Nis.14 & 2,72 & 161,0 & 57,83 & 53,35 & $-4,48$ \\
\hline May.14 & 2,82 & 175,0 & 109,9 & 105,93 & $-3,97$ \\
\hline Haz.14 & 2,72 & 161,0 & 87,34 & 83,14 & $-4,2$ \\
\hline Tem.14 & 2,59 & 144,0 & 63,54 & 58,54 & -5 \\
\hline
\end{tabular}

Uluabat Gölü su bütçesi hesaplanırken, denge denkleminde ölçüm eksikliği sebebiyle yeraltı suyunun girișinin ve çıkıșının hata payı içinde yer aldığı varsayılmıștır.

Su bütçesi denkleminde sağ tarafta olan hacimsel değișim ile eșitliğin diğer tarafında olan girenlerin ve çıkanların hacimsel farkı, yeterli ölçümün olmaması ve hassas yapılamayan ölçümlerden dolayı birbirine eșit olmamaktadır. Bu fark hata olarak tanımlanmaktadır (Mercan 2006). Çizelge 2'de Uluabat Gölü su bütçesinde olușan hatalar (kütle denkleminde gelen-çıkan farkı) gösterilmiștir. Hata, negatif olduğunda gölün beslendiğini, pozitif olduğunda ise gölden kaçak olduğunu göstermektedir (Sarmașık 2012).

Çizelge 2 incelendiğinde, hatanın maksimum değeri Ekim 2013 tarihinde $+113.781 .679 \mathrm{~m}^{3}$, minimum hata değeri ise Aralık 2013 tarihinde $-22.509 .688 \mathrm{~m}^{3}$ olarak elde edilmiștir. Bağıl hata ise $+4.423 .904,75 \mathrm{~m}^{3}$ bulunmuștur. Bu durum, genel anlamda gölde kaçak su çekimlerinin olduğunu veya gölün yeraltı suyunu beslediğini göstermektedir.

\section{SONUC̣LAR}

Su kaynaklarının sürdürülebilir kullanımı için yapılması gereken temel çalıșmalar, su havzasının hidrolojisi, hidrojeolojisi ve kirlilik araștırmalarının yapılmasıdır. Bu çalıșmada, klasik su bütçesi denklemleri kullanılarak doğal bir gölün su bütçesinin nasıl bulunacağı hem teorik hem de Uluabat Gölü'ne uygulanıșı olarak hesaplanmıștır. Bu tür konular üzerinde yapılan araștırmalar göstermiștir ki göl su seviyesindeki değișimler, yağıș akıș ve buharlașma ile ilișkilidir. Göl su seviyesi değișiminin gölün su bütçesi ve havzasındaki meteorolojik değișkenlere bağlı olduğu tespit edilmiștir.

Göl için hazırlanan su bütçesinde, önemli düzeyde hata payı bulunmaktadır. Bu durumun en önemli nedenlerinden biri gölü besleyen ve gölü boșaltan akımlarda doğru, hassas ve yeterli ölçümler yapılmamasıdır. Gölün çıkıș ayağı Kocasu Çayı́nda devamlı ölçüm yapan bir akım gözlem istasyonunun bulunmaması Uluabat Gölü için önemli bir eksikliktir. Bu durumun önlenmesi için Kocasu Çayı üzerinde ișlerliği bulunan bir Sürekli Akım Gözlem İstasyonu kurulmalıdır.

Uluabat Gölü su bütçesinin hesaplanmasında 
en önemli eksiklik yeraltı suyu verisidir. Çalıșma alanına ait herhangi bir yeraltı suyu verisi edinilememiștir. Yeraltı suyu tablasınınyüksekliğinin izlenmesi ve gölü beslediği ve gölden beslendiği dönemler belirlenerek göl hidrodinamiğine katkısı gerçekçi olarak tespit edilmelidir.

Gölün hidrolojik bilançosunun hesaplanmasında karșılașılan en büyük sorun düzenli ölçülmüș verilerin bulunmamasıdır. Gölün sürdürülebilir kullanımı açısından göle özgü meteorolojik ve akım gözlem istasyonu sayısının artırıması ile gölden çekilen su miktarı değerlerinin en doğru verilerle ölçülebilmesi için gerekli hassasiyetin gösterilmesi ve bu konuda göl çevresinde yerleșim yerlerinde bulunan halkın da bilinçlendirilmesi gerekmektedir.

\section{TEȘEKKÜR}

OUAP(M)-2013/6 nolu orta ölçekli bilimsel araștırma projemize destek vererek bu çalıșmanın gerçekleștirilmesini sağlayan Uludağ Üniversitesi Bilimsel Araștırma Projeleri Komisyonu Bașkanlığı́na teșekkür ederiz.

\section{KAYNAKLAR}

Aksoy, E. ve Özsoy, G. (2002) Investigation of MultiTemporal Land Use /Cover and Shoreline Changes of the Uluabat Lake RAMSAR Site Using RS and GIS. Uluslar arası sürdürülebilir Arazi Kullanımı ve Yönetimi Konferansı, 10-13 Haziran 2002, Çanakkale, Türkiye.

Baumgartner, A. ve Reichel, E. (1975) The World Water Balance. Münih: Elsevier. p:25-38.

Cook, P.G., Wood, C. ve Brunner, P. (2008). Groundwater Inflow to a Shallow, Poorly-mixed Wetland Estimated From a Mass Balance of Radon. Journal of Hydrology, 354, 213226.

Davraz, A. ve Balın, D. (2015) Çöl (Haydarlı/Afyon) Ovasının Hidrojeolojik ve Hidrojeokimyasal Değerlendirilmesi. Afyon Kocatepe University Journal of Science and Engineering, $10,1-22$.

Davraz, A., Sener, E., Sener, S. ve Varol, S. (2014) Water Balance of the Eğirdir Lake and the Influence of Budget Components, Isparta,Turkey. Süleyman Demirel University Journal of Natural and Applied Science 18(2), 27-36.

Davraz, A., Șener, Ș. ve Șener, E. (2016) Su Kaynaklarının Kullanma ve Koruma Metodolojisinin Geliștirilmesi: Eğirdir Gölü Havzası Örneği. Journal of Engineering Sciences and Design, 4(3), 227-238. DOI: 10.21923/jesd.71639.
Ghale, Y. A. G., A. Altunkaynak, A. Unal (2018). Investigation Anthropogenic Impacts and Climate Factors on Drying up of Urmia Lake using Water Budget and Drought Analysis. Water Resources Management January 2018, Volume 32, Issue 1, pp 325-337.

Hacısalihoğlu, S. (2016) Uluabat Gölü Su Kalitesinin Modellenmesinde Krom ve Nikel Metallerinin Değerlendirilmesi. Doktora Tezi, Uludağ Üniversitesi, Fen Bilimleri Enstitüsü, Çevre Bilimleri Anabilim Dalı, Bursa.

Hyfield, E.C.G., Day, J.W., Cable, J.E. ve Justic, D. (2008) The Impacts of Re-Introducing Mississippi River Water on the Hydrologic Budget and Nutrient Inputs of a Deltaic Estuary. Ecological Engineering, 32: 347-359.

Illeri, S., 2010. Uluabat Gölü Su ve Sediment Kalitesinin Fiziko-Kimyasal Parametreler Açısından Değerlendirilmesi ve Coğrafi Bilgi Sistemi Ortamında Analizlenmesi, Yüksek Lisans Tezi, UÜ Fen Bilimleri Enstitüsü, Bursa.

Lallahem, S. ve Mania, J. (2003) Evaluation and forecasting of daily groundwater outflow in a small chalky watershed. Hydrol Process, 17 (8), 1561-77.

Lawrie, R.A. ve Stretch, D.D. (2011) Anthropogenic impacts on the Water and Salt Budget of St Lucia Estuarine Lake in South Africa. Estuarine, Coastal and Shelf Science, 93: 58-67.

Mercan, D.E. (2006) Beyșehir Gölü'nün Hidrodinamik Modellemesi. Doktora Tezi, iTÜ Fen Bilimleri Enstitüsü, İnșaat Mühendisliği Anabilim Dalı, İstanbul.

Sarmașık, S. (2012) Uluabat Gölü Hidrodinamik Modellemesi. Yüksek Lisans Tezi, Uludağ Üniversitesi, Fen Bilimleri Enstitüsü, Çevre Bilimleri Anabilim Dalı, Bursa.

Șanlı, A.S. ve Doğan, A. (2015) Development of optimum dynamic management model of Beyșehir Lake. Journal of Engineering and Natural Sciences, Sigma 33, 144-156.

Șener, E. ve Soyaslan, I.I. (2006) Evaluation of Karstic Discharges in the East of Eğirdir Lake (Turkey) Using Satellite Images. In: The III International Scientific and Practical Conference (Use of the Water Resources and its Integretional Management in Globalization processes), Bakü , 6-7, July 2006, 70-72.

Șorman, Ü. (2008). Van Gölü su bütçesinin uzaktan algılama tekniklerinin kullanımıyla bulunması. Van Gölü Hidrolojisi ve Kirliliği Konferansı, 21-22 Ağustos 2008. 